\title{
CORRELATION BETWEEN LUMBAR SPINAL STENOSIS BASED ON MORPHOLOGY OF THE DURAL SAC AND THE QUALITY OF LIFE
}

\author{
CORRELAÇÃO ENTRE ESTENOSE LOMBAR BASEADA NA MORFOLOGIA DO SACO \\ DURAL E QUALIDADE DE VIDA

\section{CORRELACIÓN ENTRE ESTENOSIS LUMBAR BASADA EN LA MORFOLOGÍA DEL SACO DURAL Y LA CALIDAD DE VIDA}

\author{
Emílio Crisóstomo Lima Verde ${ }^{1}$, Marcelo Italo Risso Neto ${ }^{1,2}$, Sylvio Mistro Neto ${ }^{1,2}$, Ivan Guidolin Veiga ${ }^{1}$, Guilherme Rebechi Zuiani ${ }^{1,2}$ \\ Wagner Pasoualini', Marcos Antônio Tebet ${ }^{1}$, Paulo Tadeu Maia Cavali, ${ }^{1}$ \\ 1. Universidade Estadual de Campinas (Unicamp), Department of Orthopedics and Traumatology, Spine Surgery Division, Campinas, SP, Brazil. \\ 2. Hospital Alemão Oswaldo Cruz, São Paulo, SP, Brazil.
}

\begin{abstract}
Objective: To evaluate the possible existence of a significant correlation between quality of life and severity classification of lumbar stenosis based on dural sac morphology in outpatients. Methods: Forty patients with a diagnosis of lumbar stenosis followed at a university hospital were submitted to magnetic resonance imaging (MRI) and quality of life questionnaires: Oswestry Disability Index (ODI), SF-36, Swiss Spinal Stenosis Questionnaire (SSS) and EQ-5D. They were classified as type A, B, C or D based on MRI. For the statistical analysis, the Spearman correlation was used. Results: Seventeen female patients and 23 male patients with mean age of 56.5 years constituted the sample. ODI had a mean dysfunction of $44.9 \%$, the PCS score averaged 29.9, the MCS score was 41.3 . The general symptoms of SSS presented a mean of 3.2 and the EQ-5D presented an average of 0.491 . The patients with the highest severity in the classification were not necessarily those who presented worse scores in the quality of life questionnaires. Conclusion: The classification of severity of the lumbar spinal stenosis based on dural sac morphology does not correlate with the applied quality of life questionnaires. Level of Evidence III; Cross-sectional observational study.
\end{abstract}

Keywords: Spinal stenosis; Quality of life; Magnetic resonance imaging.

\section{RESUMO}

Objetivo: Avaliar a possível existência de uma correlação significativa entre a classificação de gravidade da estenose lombar baseada na morfologia do saco dural e a qualidade de vida em pacientes ambulatoriais. Método: Quarenta pacientes com diagnóstico de estenose lombar, acompanhados em um hospital universitário, foram submetidos ao exame de Ressonância Magnética (RM) e a questionários de qualidade de vida: Oswestry Disability Index (ODI), SF-36, Swiss Spinal Stenosis Questionnaire (SSS) e EQ-5D. Foram classificados em tipo $A, B, C$ ou $D$, baseados na RM. Na análise estatística, foi realizada a correlação de Spearman. Resultados: 17 pacientes do sexo feminino e 23 do sexo masculino com média de idade de 56,5 anos. ODI apresentou uma disfunção média de 44,9\%, o PCS escore médio de 29,9, o MCS de 41,3. Os Sintomas gerais do SSS apresentaram média de 3,2 e o EQ-5D apresentou média de 0,491. Os pacientes com maior gravidade da classificação não foram, necessariamente, os que apresentaram piores escores nos questionários de qualidade de vida. Conclusão: Classificação de estenose lombar baseada na morfologia do saco dural não apresenta correlação com os questionários de qualidade de vida aplicados. Nível de Evidência III; Estudo observacional analítico transversal.

Descritores: Estenose Espinal; Qualidade de Vida; Imagem por Ressonância Magnética.

\section{RESUMEN}

Objetivo: Evaluar la posible existencia de una correlación significativa entre la calidad de vida y la clasificación de la gravedad de la estenosis lumbar basada en la morfología del saco dural en pacientes ambulatorios. Métodos: Cuarenta pacientes con diagnóstico de estenosis lumbar seguidos en un hospital universitario fueron sometidos a resonancia magnética (RM) y a cuestionarios de calidad de vida: Índice de Discapacidad de Oswestry (ODI), SF-36, Swiss Spinal Stenosis Questionnaire (SSS) y EQ-5D. Se clasificaron como tipo A, B, C o D según la resonancia magnética. Para el análisis estadístico, se utilizó la correlación de Spearman. Resultados: Diecisiete pacientes del sexo femenino y 23 del sexo masculino con una edad promedio de 56,5 años constituyeron la muestra. El ODI tuvo una disfunción promedio de 44,9\%, la puntuación PCS fue en media 29,9, la puntuación MCS fue de 41,3. Los síntomas generales de SSS presentaron una media de 3,2 y el EQ-5D presentó una media de 0,491. Los pacientes con mayor gravedad en la clasificación no fueron necesariamente los que presentaron puntuaciones peores en los cuestionarios de calidad de vida. Conclusión: La clasificación de la gravedad de la estenosis lumbar basada en la morfología del saco dural no se correlaciona a los cuestionarios de calidad de vida aplicados. Nivel de evidencia III; Estudio observacional analítico transversal.

Descriptores: Estenosis espinal; Calidad de vida; Imagen por resonancia magnética. 


\section{INTRODUCTION}

The term lumbar stenosis is commonly used to describe patients with symptoms related to the anatomic reduction of the diameter of the lumbar spine, but this anatomic definition is not sufficient to determine the severity of the symptoms and functional impairment of the patient. To date, the criteria for diagnosis and classification are still not widely accepted, leading studies to use different eligibility criteria, thus limiting the generalization of the reported results. ${ }^{1-3}$

It is classified as primary or secondary, ${ }^{2,4}$ congenital stenosis being rare, presenting short pedicles, and narrowing of the spinal canal. Secondary stenosis is associated with degenerative changes to the spinal joint complex. ${ }^{5}$

Its diagnosis is based on clinical history, physical examination, and confirmatory imaging examinations, with the main symptoms being neurogenic claudication, pain, and paresthesia in the lower limbs. ${ }^{4-6}$

Additional signs are important and desired in guiding a surgical decision..$^{3,7}$ In this way, the measurement of the area of the cross-section of the dural sac and the anteroposterior diameter have come to be used as evidence of stenosis of the lumbar canal. ${ }^{8}$ Also, in 2008, Landim developed a classification system based on morphopathological criteria related to the etiology and location of the compression of the neural elements, which helped in the identification of the pathology of stenosis, guiding the selection of the best surgical approach. ${ }^{9}$

In this context, a new study developed a lumbar stenosis classification based on the morphology of the dural sac. ${ }^{10}$ The classification is made using axial magnetic resonance slices in T2 of the levels to be evaluated, taking the cerebrospinal fluid and the disposition of the roots into account. (Figure 1) ${ }^{10}$ Seven grades were described separated into A (subtypes 1, 2, 3, and 4), B, C, and D. ${ }^{10}$

It was determined that grade $A$ represented mild stenosis, $B$, moderate stenosis, C, severe stenosis, and D, extreme stenosis. It is thought to be a better definition of stenosis than other classifications because it takes the degree of involvement of the contents inside the dural sac into account. ${ }^{10}$

Measuring the quality of life of these patients is an important tool in the conduct of each case, since it refers to the dimensions of life that can be affected by diseases or their treatment. ${ }^{11}$ We know that lumbar stenosis, when symptomatic, has a direct negative impact on patient quality of life and is associated with physical, social, and psychological disability, ${ }^{12-14}$ leading to deficits four times greater than those of the general population after adjusting for age and comorbidities. ${ }^{15}$

Among the questionnaires used to evaluate quality of life were the Oswestry Disability Index (ODI), ${ }^{16}$ the SF-36, ${ }^{17}$ the Swiss Spinal Stenosis Questionnaire (SSS), ${ }^{18}$ and the EQ-5D. ${ }^{19,20}$

The objective of this study was the evaluate the correlation between the classification of the severity of lumbar stenosis based on the morphology of the dural sac and the quality of life assessed by specific questionnaires in symptomatic patients with a diagnosis of lumbar canal stenosis.

\section{METHODS}

This was a cross-sectional study, conducted at the outpatient clinic of a public university hospital. All the patients were referred to the hospital for evaluation by the spine group due to symptoms suggesting lumbar stenosis.

To initiate the study, patients with a clinical suspicion of and a physical examination compatible with lumbar canal stenosis were evaluated during the period from April 2015 to November 2016.

The exclusion criteria were patients with a history of spine surgery, spinal tumors, and deformities greater than 45 degrees in the coronal plane of the spine, and those who did not agree to participate in the study. Patients with a contraindication to magnetic resonance and those younger than 18 or older than 80 years of age were also excluded.

In the consultations with these patients, four quality of life questionnaires were administered by the same member orthopedic physician. The questionnaires administered were the Oswestry Disability Index, the SF-36, the Swiss Spinal Stenosis Questionnaire, and the EQ-5D.

All selected patients underwent magnetic resonance examinations in regional clinics. This examination is considered the gold standard for radiological diagnosis of stenosis, and, therefore, is a part of the protocol to be followed in these cases. ${ }^{10}$ The study was approved by the Institutional Review Board as CAAE number 51530015.2.0000.5404. All study participants signed the Informed Consent Form.

The magnetic resonance results were evaluated by two experienced spine surgeons using the OsiriX DICOM Viewer system. The lumbar level with the worst involvement was classified using the lumbar stenosis severity classification based on the morphology of the dural sac and adapted from Schizas et al. ${ }^{10}$ The adaptation made was to divide group A into only two subgroups instead of four, as in the original. The criterion used for the subdivision was the nerve root sedimentation sign, which is present in $A 1$ and $A 2$ (being designated $A-1$ ) and absent in A3 and A4 (being designated $\mathrm{A}-2$ ) ${ }^{3}$

After the questionnaires were applied and the respective scores calculated, the data used were the percentage of dysfunction as determined by the ODI, the physical (PCS) and mental (MCS) function scores and symptom severity scales (painful and neuroischemic) found in the SF-36, the physical function scale as measured by the SSS, in addition to the scores from the EQ-5D questionnaire. Patient satisfaction, which is a part of the SS, was not used because none of the patients had yet been submitted to surgical treatment.

The personal characteristics, the morphological classification of the dural sac, and the quality of life scores were described using summary measurements (mean, median, minimum, maximum) or absolute and relative frequencies. ${ }^{21}$

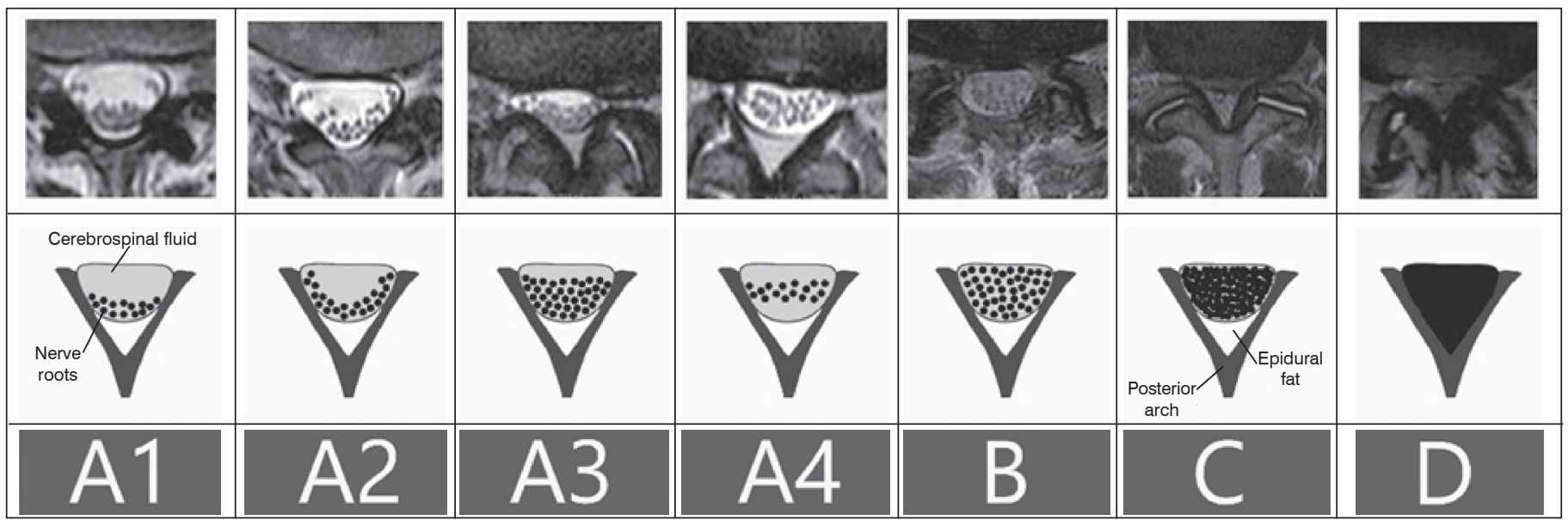

Figure 1. Classification of lumbar stenosis based on the morphology of the dural sac (adapted from Schizas et al.). 
Spearman correlations between the classification and all the quality of life scores, as well as the correlations between the quality of life scores, were calculated. ${ }^{21}$

The analyses were conducted using IBM-SPS for Windows version 20.0 software and the tables were built using Microsoft-Excel 2003 software. The tests were performed with a significance level of $5 \%$.

\section{RESULTS}

After applying the inclusion and exclusion criteria (Table 1), the sample was composed of 40 patients, 23 of them males (57.5\%). Of these, 10 were classified as A-1, 5 as A-2, 8 as B, 12 as C, and 5 as $D$. Therefore, more than $60 \%$ of the patients assessed were classified as B or above, with most of these classified as C (30\%). The mean patient age was 56.5 years (minimum of 23 and maximum of 79 ).

The Oswestry Disability Index had a mean score of 44.9, which indicates a norm of severe incapacity in the population studied. In the SF-36, the mean physical function component score (PCS) was 29.9, while the mental health component score (MCS) averaged 41.3. The assessment of the general symptoms of the population using the Swiss Spinal Stenosis questionnaire yielded a mean score of 3.2. The maximum possible score would be 5, indicating the worst symptoms, and the minimum possible score would be 1 , indicating better health. When physical function was evaluated, the mean presented was 2.6 out of a possible 4 (worst function) and a minimum of 1 (better function). The mean score from the EQ-5D questionnaire, in which the closer the score is to 1 , the better the quality of life, was 0.491 .

The classification had a direct correlation with the ODI and the subdivisions of the SSS. However, there was an inverse correlation with the SF-36 and the EQ-5D.

The results of the statistical analysis showed that practically all the relationships between the classifications and the questionnaires had an absolute value of less than 0.2 (Table 2), and thus were not statistically significant. Among all the questionnaires, the EQ-5D presented the weakest relationship $(r=0.083)$. The only relationship greater than 0.2 was between the classification and the general symptoms of the Swiss questionnaire, but it was not statistically significant $(p>0.05)$

\section{DISCUSSION}

With the increased life expectancy of the population due to lifestyle changes and the practice of healthy activities, degenerative conditions of several joints and of the lumbar spine play a much greater role in the day-to-day routine of spine surgeons. ${ }^{1-3}$

Several tools for the better diagnosis, classification, and treatment of these illnesses are described in the literature. $6,7,10-12$

In patients with lumbar stenosis, magnetic resonance can show the degree of narrowing, the characteristics of structures, such as the disc and the ligamentum flavum, and the disposition of the nerve roots at high quality. $3,6,7,10$

However, Boden et al. ${ }^{22}$ showed that magnetic resonance revealed spinal stenosis in $20 \%$ of asymptomatic patients over 60 years of age. Years later, Haig et al. ${ }^{23}$ separated the patients in their study into three groups based on the results of a clinical neurological evaluation: without pain, mechanical back pain, and clinical lumbar stenosis. The measurements from the magnetic resonance were not able to differentiate the patients with clinical spinal stenosis from those in the control group. Thus, they believe that isolated imaging exams do not guide treatment of stenosis of the canal and a clinical evaluation is of utmost importance in making a decision. ${ }^{22,23}$

Other studies have reported similar results, not only in treating lumbar stenosis, but also in cases of disc herniation. ${ }^{11,13}$

In the study by Ogikubo et al., ${ }^{24}$ it was shown that the area of the dural sac is a powerful predictor of preoperative walking ability, pain, and quality of life questionnaire scores. In another more recent study, Kanno et al. ${ }^{25}$ reported a correlation between the severity of preoperative symptoms and the area of an MRI axial slice of the dural sac in patients selected for surgical procedures. ${ }^{24,25}$
Table 1. Description of results.

\begin{tabular}{|c|c|}
\hline Variable & $\begin{array}{c}\text { Description } \\
(N=40)\end{array}$ \\
\hline \multicolumn{2}{|l|}{ Sex, n (\%) } \\
\hline $\mathrm{F}$ & $17(42.5)$ \\
\hline $\mathrm{M}$ & $23(57.5)$ \\
\hline \multicolumn{2}{|l|}{ Classification, n (\%) } \\
\hline $\mathrm{A}-1$ & $10(25)$ \\
\hline A-2 & $5(12.5)$ \\
\hline $\mathrm{B}$ & $8(20)$ \\
\hline $\mathrm{C}$ & $12(30)$ \\
\hline $\mathrm{D}$ & $5(12.5)$ \\
\hline \multicolumn{2}{|l|}{ Age (years) } \\
\hline Mean \pm SD & $56.5 \pm 12$ \\
\hline Median (min.; max.) & $56.5(23 ; 79)$ \\
\hline \multicolumn{2}{|l|}{ Oswestry } \\
\hline Mean \pm SD & $44.9 \pm 16.5$ \\
\hline Median (min.; max.) & $43(20 ; 72)$ \\
\hline \multicolumn{2}{|l|}{ PCS } \\
\hline Mean \pm SD & $29.9 \pm 8.8$ \\
\hline Median (min.; max.) & $29(4 ; 46)$ \\
\hline \multicolumn{2}{|l|}{ MCS } \\
\hline Mean \pm SD & $41.3 \pm 11.6$ \\
\hline Median (min.; max.) & $38.6(22 ; 65)$ \\
\hline \multicolumn{2}{|l|}{ SSS (symptoms) } \\
\hline Mean \pm SD & $3.2 \pm 0.63$ \\
\hline Median (min.; max.) & $3.22(2 ; 5)$ \\
\hline \multicolumn{2}{|l|}{ SSS (painful) } \\
\hline Mean \pm SD & $3.62 \pm 0.65$ \\
\hline Median (min.; max.) & $3.63(2 ; 5)$ \\
\hline \multicolumn{2}{|l|}{ SSS (neuroischemic) } \\
\hline Mean \pm SD & $2.65 \pm 0.94$ \\
\hline Median (min.; max.) & $2.67(1 ; 4.33)$ \\
\hline \multicolumn{2}{|l|}{ SSS (physical function) } \\
\hline Mean \pm SD & $2.6 \pm 0.56$ \\
\hline Median (min.; max.) & $2.8(1.6 ; 3.6)$ \\
\hline \multicolumn{2}{|l|}{ EQ-5D } \\
\hline Mean \pm DP & $0.491 \pm 0.251$ \\
\hline Median (min.; max.) & $0.446(0.049 ; 0.843)$ \\
\hline
\end{tabular}

Table 2. Correlations between the morphological classification and the quality of life scores ( $r$ = relationship, $p=$ level of significance).

\begin{tabular}{c|c|c}
\hline \multicolumn{2}{c|}{ Correlation } & Classification \\
\hline \multirow{2}{*}{ Oswestry } & $\mathrm{r}$ & -0.118 \\
\cline { 2 - 3 } & $\mathrm{p}$ & 0.467 \\
\hline \multirow{2}{*}{ PCS } & $\mathrm{r}$ & 0.191 \\
\cline { 2 - 3 } & $\mathrm{p}$ & 0.238 \\
\hline \multirow{2}{*}{ MCS } & $\mathrm{r}$ & 0.146 \\
\cline { 2 - 3 } & $\mathrm{p}$ & 0.369 \\
\hline \multirow{2}{*}{ SSS (symptoms) } & $\mathrm{r}$ & 0.205 \\
\cline { 2 - 3 } & $\mathrm{p}$ & 0.205 \\
\hline \multirow{2}{*}{ SSS (painful) } & $\mathrm{r}$ & 0.111 \\
\cline { 2 - 3 } & $\mathrm{p}$ & 0.494 \\
\hline \multirow{2}{*}{ SSS (neuroischemic) } & $\mathrm{r}$ & 0.186 \\
\cline { 2 - 3 } & $\mathrm{p}$ & 0.251 \\
\hline \multirow{2}{*}{ SSS (physical function) } & $\mathrm{r}$ & 0.113 \\
\cline { 2 - 3 } & $\mathrm{p}$ & 0.488 \\
\hline \multirow{2}{*}{ EQ-5D } & $\mathrm{r}$ & -0.083 \\
\cline { 2 - 3 } & $\mathrm{p}$ & 0.612 \\
\hline
\end{tabular}

Spearman Correlation $^{19}$ 
Classification of the severity of lumbar stenosis based on the morphology of the dural sac is one of the more recent tools that try to stratify the degree of canal stenosis and its relationship with the nerve roots using magnetic resonance images. ${ }^{10}$

Since all patients who underwent magnetic resonance presented some degree of neurological change in the physical examination, one of the ways to clinically separate these patients is to apply quality of life questionnaires to define the impact of stenosis on their daily lives. ${ }^{13-19}$

In this study, the classification assessed was directly correlated with the Oswestry Disability Index (ODI) scores, but we did not find a significant relationship between them. It has already been shown in the literature that the ODI did not have a significant relationship with the area of the cross-section of the dural sac, or with the narrowing observed in radiological studies either in patients with and without spondylolisthesis. ${ }^{12,26,27}$

The relationship was inversely proportional in the SSF-36. ${ }^{17} \mathrm{How}-$ ever, there was no statistically significant correlation in this study, taking the PCS and MCS into account. Therefore, the severity of the narrowing and the characteristics of the root position within the canal did not necessarily lead to worse physical and mental scores being evaluated by the questionnaire.

The analysis performed with the Swiss Spinal Stenosis Questionnaire (SSS) was through a direct correlation with the classification. ${ }^{18}$ In our study, none of the aspects evaluated by the SSS showed a correlation with the types of stenosis graded using resonance - a particularly relevant finding, since this questionnaire is already widely used and focused on the specific type of infirmity that we are evaluating. ${ }^{18}$
When the classification was correlated with the EQ-5D questionnaire, the outcome was no different. It was not possible to confirm an inverse correlation as had been expected. In several cases, the scores were quite similar despite the great difference in the degree of stenosis assessed using the morphology of the dural sac. ${ }^{19,20}$

Just as in our study, Amundsen et al. ${ }^{28}$ were not able to establish a relationship between the severity of the stenosis and the clinical findings, even after ten years of follow-up. Additionally, four other studies did not observe any relationship between the preoperative symptoms and the MRI findings. 8,12,26-28

We believe that on the positive side of the classification is its assessment of the disposition of the nerve roots within the narrow canal, while on the negative side, we note the subjective measurement of the area of the central canal, in addition to the fact that it does not consider the possibility of foraminal stenosis, which, in many cases, may be the cause of the main clinical complaint of the patient. Therefore, it is not sufficient to define the severity level of the case.

\section{CONCLUSION}

The classification of lumbar stenosis based on the morphology of the dural sac presented no correlation with any of the quality of life questionnaires administered routinely in this study in the monitoring of patients with lumbar stenosis.

All authors declare no potential conflict of interest related to this article.

CONTRIBUTION OF THE AUTHORS: Each author made significant individual contributions to this manuscript. ECLV (0000-0002-9008-7239)* MIRN (0000-0003-0990-6901)*, and SMN (0000-0002-1890-0520* were the main contributors to the writing of the manuscript. GRZ (0000-0002-4240-9096)*, IGV (0000-0001-7221-5447)*, and PTMC (0000-0001-5226-505X)* followed-up with the patients and administered the questionnaires. ECLV and MAT (0000-0003-0346-3564)* interpreted the radiological examinations. MIRN, WP (0000-0002-0464-3455)*, and MAT performed the bibliographical research and evaluated the statistical analysis data. SMN, MIRN, GRZ, IGV, and PTMC contributed to the intellectual concept of the study. ECLV, SMN, and MIRN reviewed the manuscript. *ORCID (Open Researcher and Contributor ID).

\section{REFERENCES}

1. Genevay S, Atlas SJ. Lumbar spinal stenosis. Best Pract Res Clin Rheumatol. 2010; 24(2):253-65.

2. Goh KJ, Khalifa W, Anslow P, Cadoux-Hudson T, Donaghy M. The clinical syndrome associated with lumbar spinal stenosis. Eur Neurol. 2004;52(4):242-9.

3. Resende VAC, Teixeira A, Silva JB, Neto AC, Leal FJF, Gouveia ARF, et al. Canal lombar estreito. Sinal da Sedimentação. Rev Coluna/Columna. 2013;12(3):192-5.

4. Matsumoto M, Watanabe K, Tsuji T, Ishii K, Takaishi H, Nakamura M, et al. Nocturnal leg cramps: a common complaint in patients with lumbar spinal canal stenosis. Spine (Phila Pa 1976). 2009;34(5):E189-94.

5. Abbas J, Hamoud K, May H, Hay O, Medlej B, Masharawi Y, et al. Degenerative lumbar spinal stenosis and lumbar spine configuration. Eur Spine J. 2010;19(11):1865-73.

6. Christy C, Tomkins L, Quint DJ, Gabriel S, Melloh M, Haig AJ. Nerve Root Sedimentation Sign for the Diagnosis of Lumbar Spinal Stenosis: Reliability, Sensitivity, and Specificity. Spine (Phila Pa 1976). 2013;38(24):1554-60.

7. Thomas Barz T, Melloh M, Staub LP, Lord SJ, Lange J, Roder CP, et al. Nerve Root Sedimentation Sign Evaluation of a New Radiological Sign in Lumbar Spinal Stenosis. Spine (Phila Pa 1976). 2010;35(8):892-7.

8. Sigmundsson FG, Kang XP, Jönsson $B$, Strömqvist $B$. Correlation between disability and MRI findings in lumbar spinal stenosis. A prospective study of 109 patients operated on by decompression. Acta Orthop. 2011;82(2):204-10

9. Landim E. A new classification for lumbar stenosis. Rev Coluna/Columna. 2008:7(2):97-100

10. Schizas C, Theumann N, Burn A, Tansey R, Warlaw D, Smith FW, et al. Qualitative grading of severity of lumbar spinal stenosis based on the morphology of the dural sac on magnetic resonance images. Spine (Phila Pa 1976). 2010;35(21):1919-24.

11. Jansson $K \AA$, Németh $G$, Granath $F$, Jönsson B, Blomqvist P. Health-related quality of life in patients before and after surgery for a herniated lumbar disc. J Bone Joint Surg Br. 2005;87(7): 959-64

12. Sirvanci M, Bhatia M, Ganiyusufoglu KA, Duran C, Tezer M, Ozturk C, et al. Degenerative lumbar spinal stenosis: correlation with Oswestry Disability Index and MR Imaging. Eur Spine J. 2008;17(5):679-85

13. Saban KL, Penckofer SM, Androwich I, Bryant FB. Health-related quality of life of patients following selected types of lumbar spinal surgery: A pilot study. Health Qual Life Outcomes. 2007;5:71

14. Otani K, Kikuchi S, Yabuki S, Igarashi T, Nikaido T, Watanabe K, et al. Lumbar spinal stenosis has a negative impact on quality of life compared with other comorbidities: an epidemiological cross-sectional study of 1862 community-dwelling individuals. ScientificWorldJournal. 2013;2013:590652.
15. Battié MC, Jones CA, Schopfloch DP, Hu RW. Health-related quality of life and comorbidities associated with lumbar spinal stenosis. Spine J. 2012;12(3):189-95.

16. Fairbank JCT, Pynset PB. The Oswestry Disability Index. Spine (Phila Pa 1976) 2000:25(22):2940-53.

17. Ciconelli RM et al. Tradução para o português e validação do questionário genérico de avaliação de qualidade de vida SF-36 (Brasil SF-36). Rev Bras Reumatol. 1999;39(3):143-50.

18. Azuaga TL, Cavali PTM, Risso Neto MI, Zuiani GR, Pasqualini W, Veiga IG, et al. Tradução e adaptação transcultural para língua portuguesa do "Swiss Spinal Stenosis Questionnaire" Coluna/Columna. 2013;12(1):36-41.

19. Brooks R. EuroQol: the current state of play. Health Policy. 1996;37(1):53-72.

20. EuroQol. EuroQolProducts. Disponível em: http://www.euroqol.org/. Acesso em outubro de 2016.

21. Kirkwood BR, Sterne JAC. Essential medical statistics. 2nd ed. Massachusetts, USA Blackwell Science; 2006

22. Boden SD, Davis DO, Dina TS, Patronas NJ, Wiesel SW. Abnormal magnetic-resonance scans of the lumbar spine in asymptomatic subjects. J Bone Joint Surg Am. 1990:72(3):403-8.

23. Haig AJ, Geisser ME, Tong HC, Yamakawa KS, Quint DJ, Hoff JT, et al. Electromyographic and magnetic resonance imaging to predict lumbar spinal stenosis, low-back pain, and no back symptoms. J Bone Joint Surg Am. 2007;89(2):358-66.

24. Ogikubo O, Forsberg $L$, Hansson T. The relationship between the cross-sectional area of the cauda equina and preoperative symptoms in central lumbar spinal stenosis. Spine (Phila Pa 196). 2007;32(13):1423-8.

25. Kanno H, Ozawa H, Koizumi Y, Morozumi N, Aizawa T, Kusakabe T, et al. Dynamic change of dural sac cross-sectional area in axial loaded magnetic resonance imaging correlates with the severity of clinical symptoms in patients with lumbar spinal canal stenosis. Spine (Phila Pa 1976). 2012;37(3):207-13

26. Pasqualini W Risso MI, Zuiani GR, Miranda JB. Estenose degenerativa do canal lombar: correlação entre o índice de Oswestry e imagem de ressonância magnética. Coluna/ Columna, 2012;11(4):278-82.

27. Kuittinen $P$, Sipola P, Saari T, Aalto TJ, Sinikallio S, Savolaine S, et al. Visually assessed severity of lumbar spinal canal stenosis is paradoxically associated with leg pain and objective walking ability. BMC Musculoskeletal Disord. 2014;15:348.

28. Amundsen T, Weber H, Nordal HJ, Magnaes B, Abdelnoor M, Lilleås F. Lumbar spinal stenosis: Conservative or surgical management? A prospective 10-year study. Spine (Phila Pa 1976). 2000;25(11):1424-36 